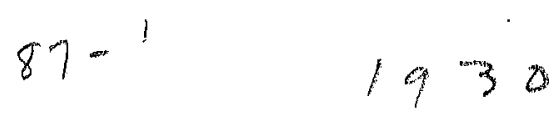

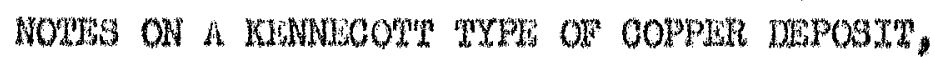

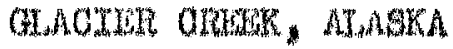

Alan Natoman.

$$
\begin{aligned}
& \begin{aligned}
k+87-1 \\
87-25 \\
87-26
\end{aligned} \\
& 81-21
\end{aligned}
$$

Introduction.

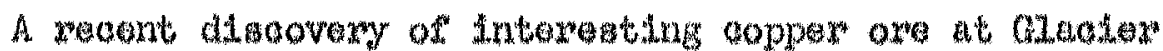
Oroek, Alakk, dialorad anotho* doposti of the Konmecott type of

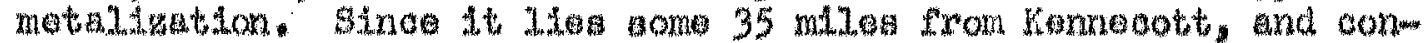

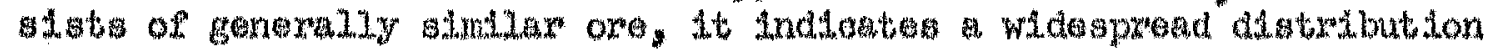

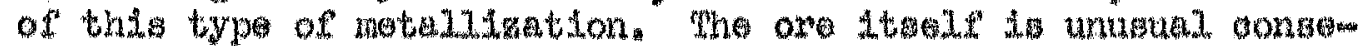
quently a fow rotes about the depost may ba of Interest.

The depost Ites an alevation of 3,100 foet on the

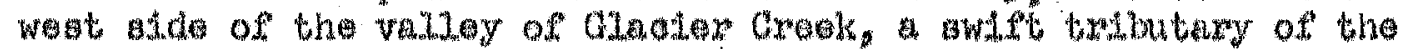

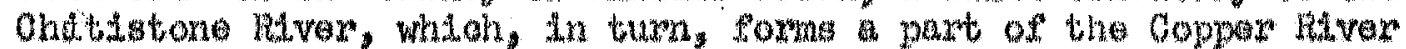

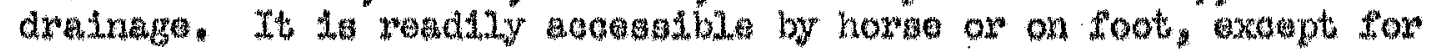

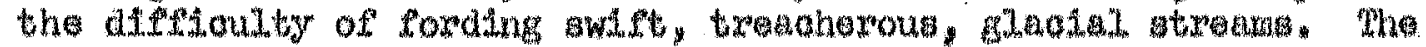

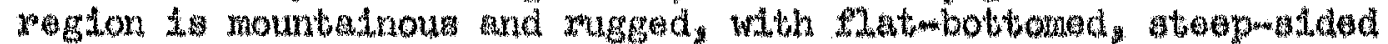

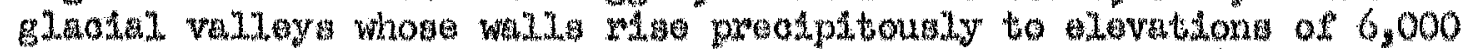

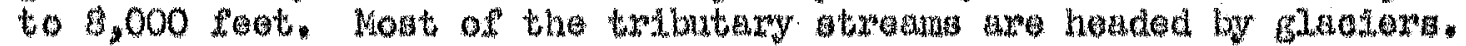

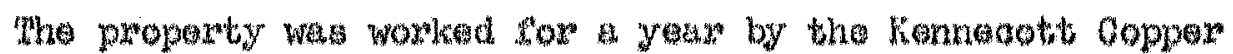
Corporation but was abendoned in 1930. It was studtod by the writer.

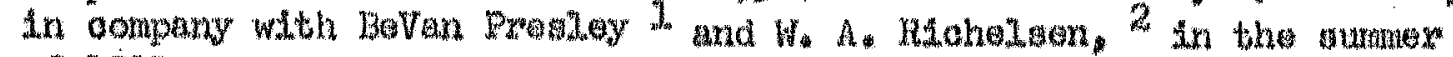
of 1930.

\title{
GNHLAL OEOLOOY.
}

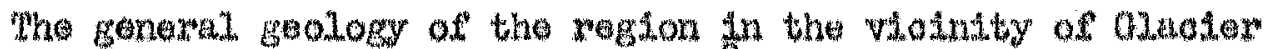

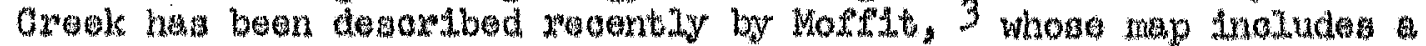

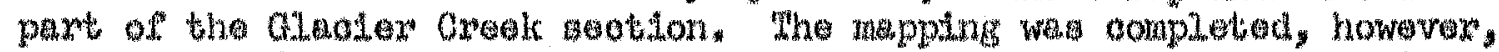

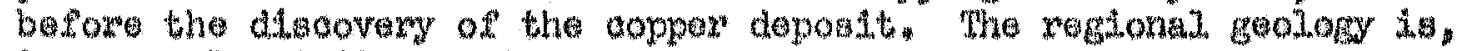

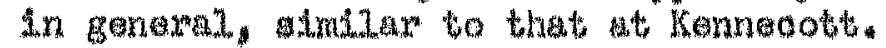

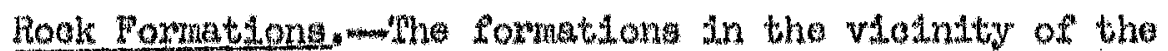

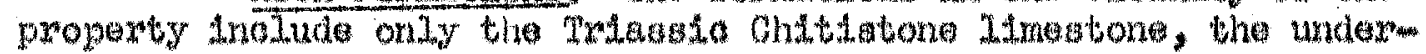

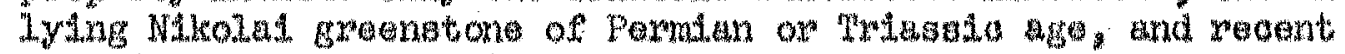
dopostis, ohterly surtomglacked.

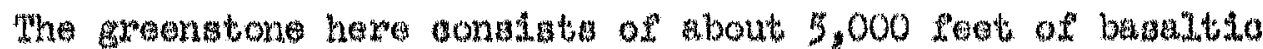
Iava flown, altured for the nots parts, and atalned widely with ooppos minerals. It forms the middie and lowar siopes of the validey wallos.

Ihe chitiatone Linoatone in thia viounty its abont 2,000 feot

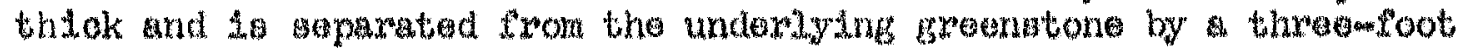

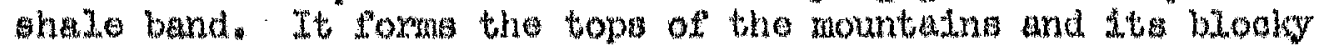

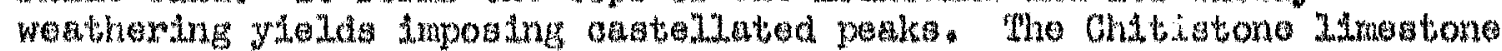

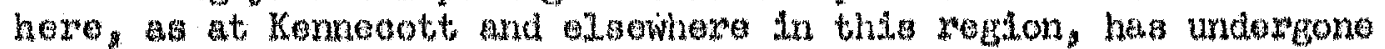

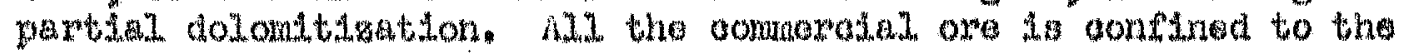


to the Ondthatone Pormation.

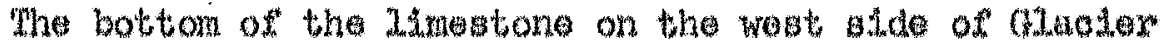
creak Lies at alevations of tron 4,000 to 6,000 feet the greenstone extonds down to the creek level at an wovation of 2,500 foet.

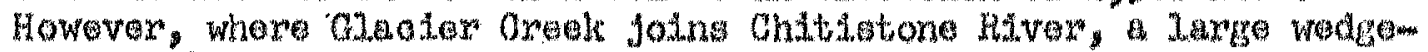

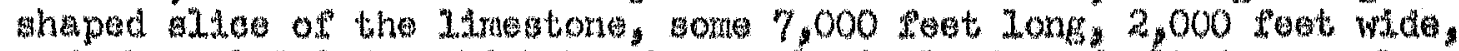

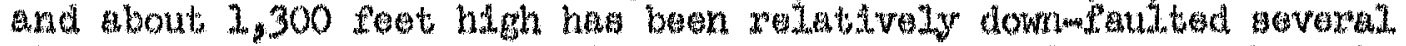

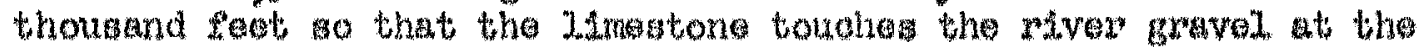

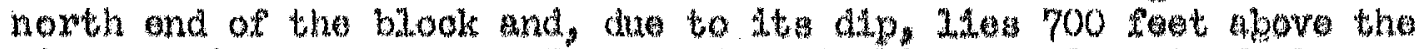

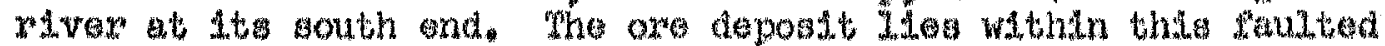
Inestone blook.

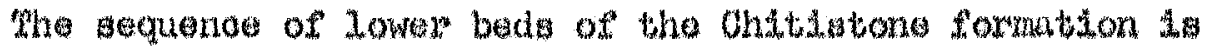

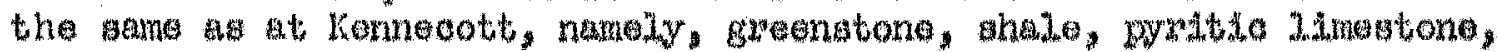
black limostone, gray linestono, and gray dolomitu.

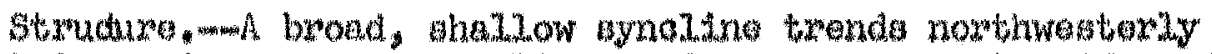

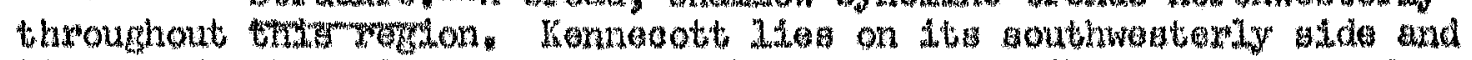

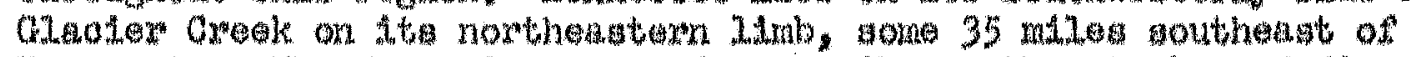

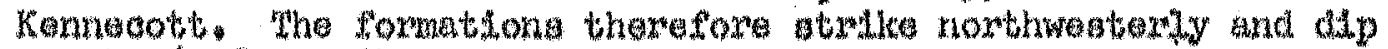
centiy $\left(15^{\circ}-20^{\circ}\right)$ to the couthwat.

A great thate sault with a soubhwesterly dip has bean

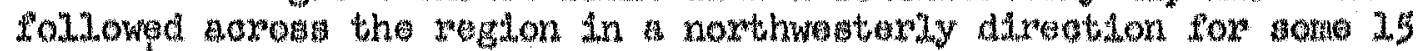

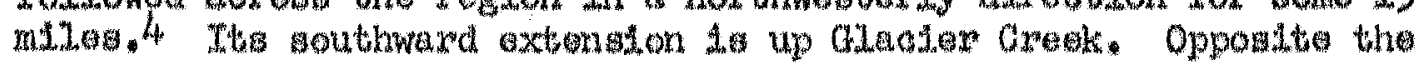

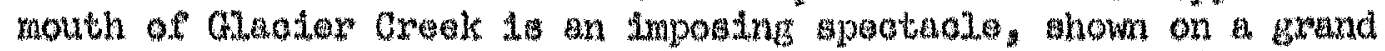

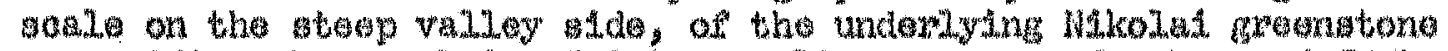

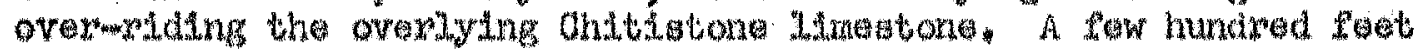

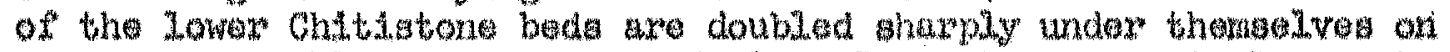

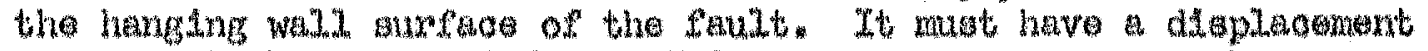

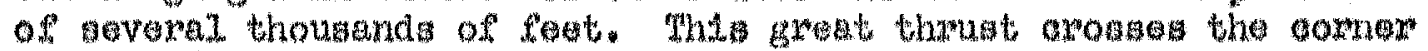

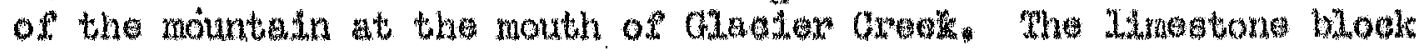

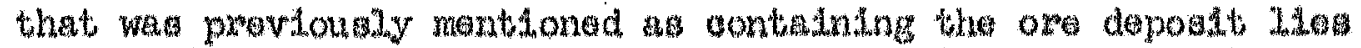

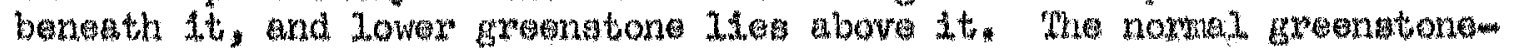

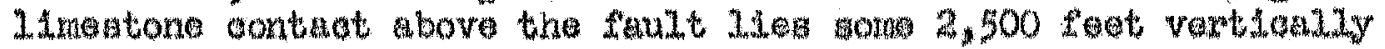

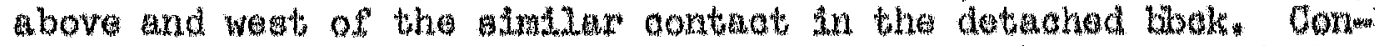
sequentiy, the throw os the saul wast bo geveral thousand fout and the displacement along the faut arface muh greater.

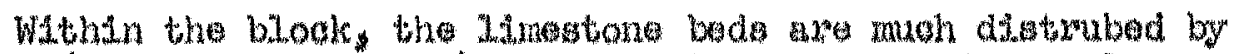

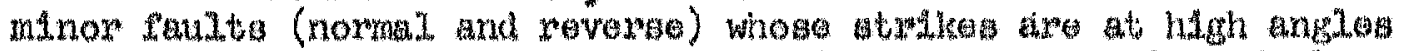

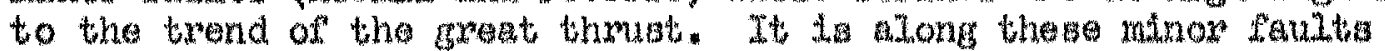

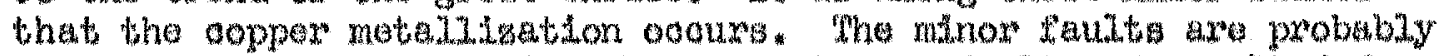

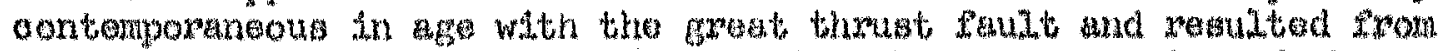

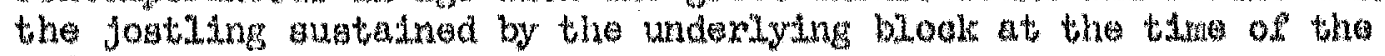
ma jow movernent.

Where has also boen oons that aldolocated the oxe.

ORE DEPOSYTS.

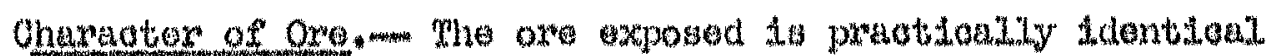

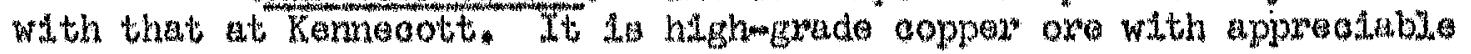




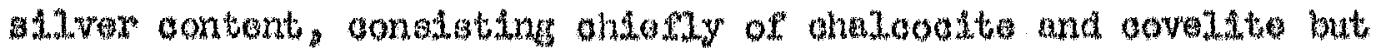

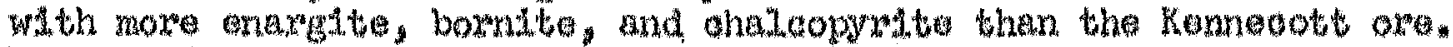

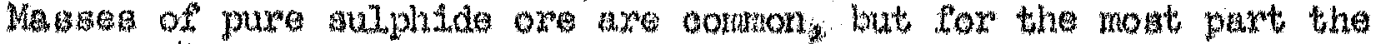
ooppex ratnexals ocour as blebs on bunches Inolosed in axpondte dook.

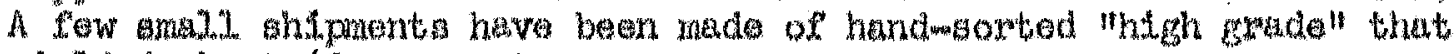
Yiteided about 60 per cont aopper.

Nature of pepostts me the ore dsolosed oocurs in staoply

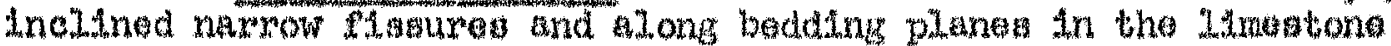

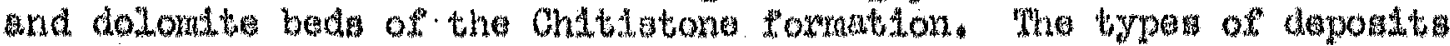

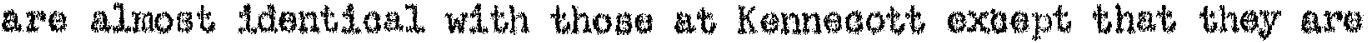
amallex and more dLoontimous.

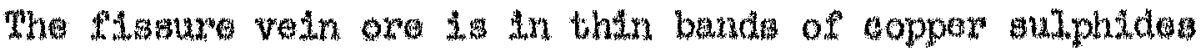

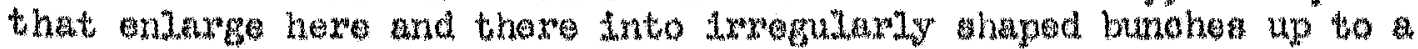

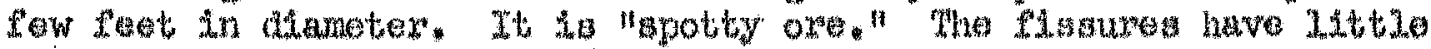

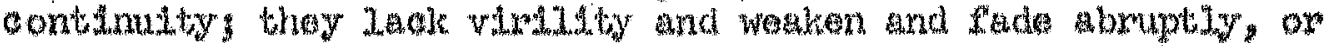

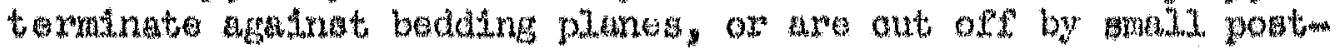
mineral faulta.

The beddure plane oxe conaksts of thin bands o* bunohea of

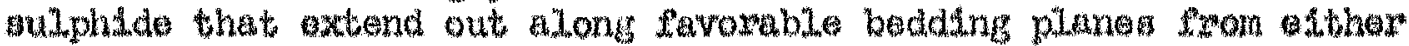

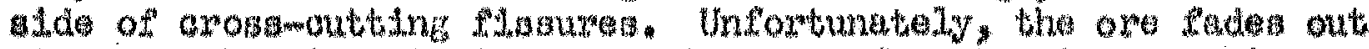

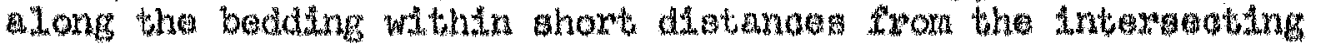

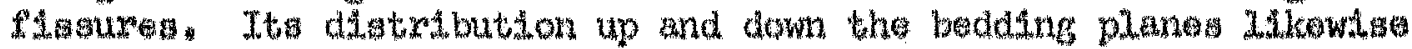

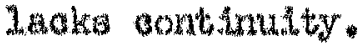

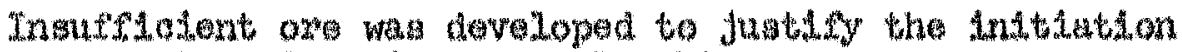
of expengtve oparations in this zenoto localdty.

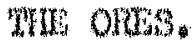

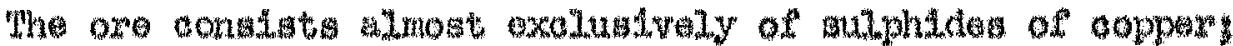

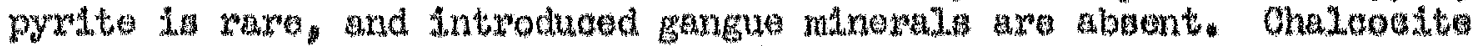

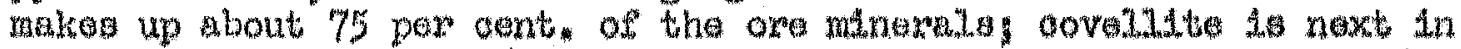

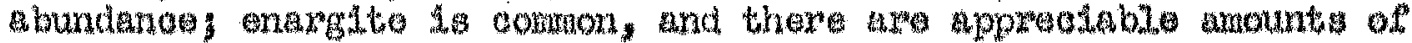

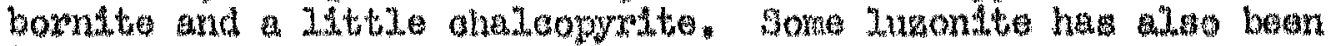

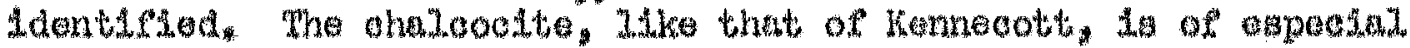
intureat.

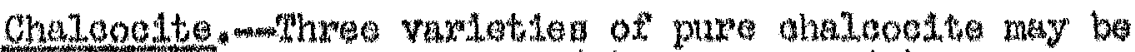

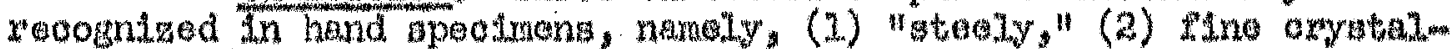

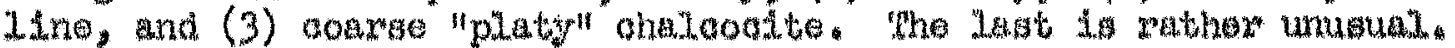

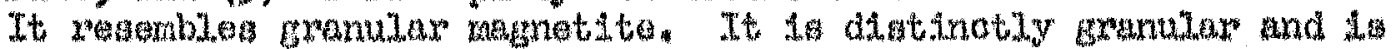

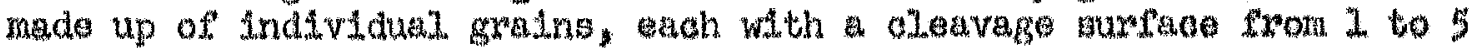

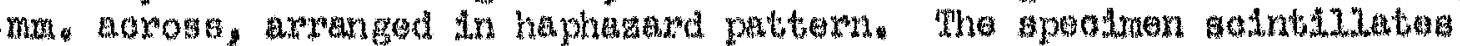

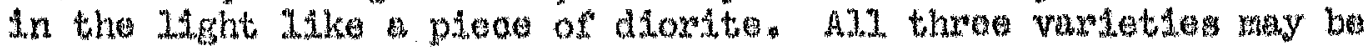

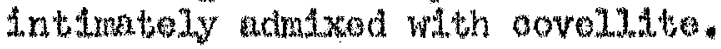

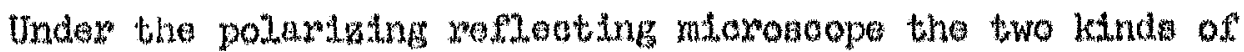

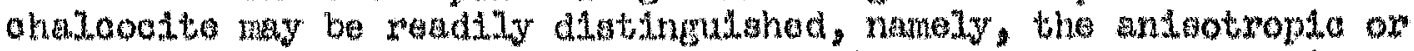

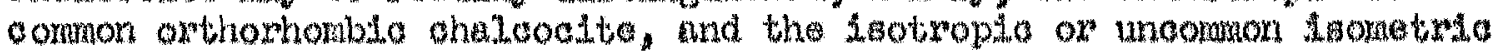

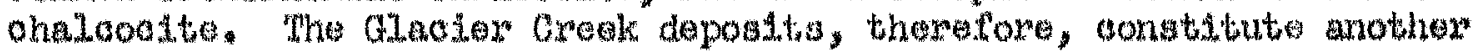

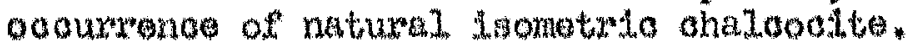




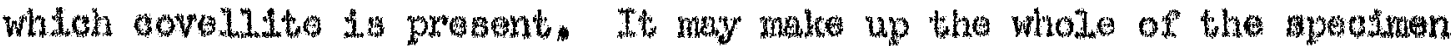

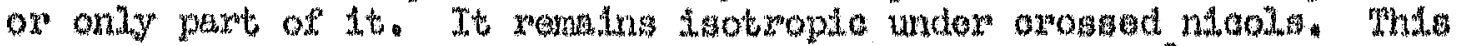

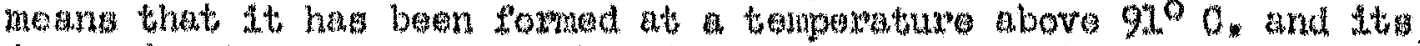

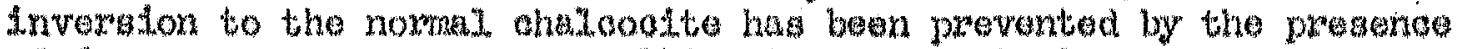

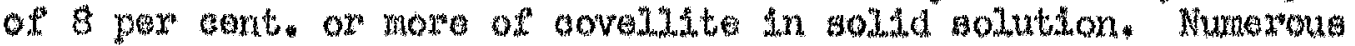

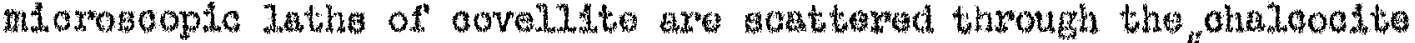
ard axe of the type that has been formed by exmolution.

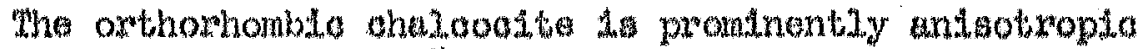

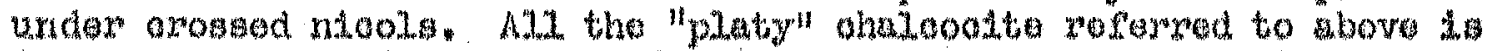

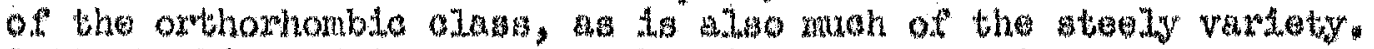

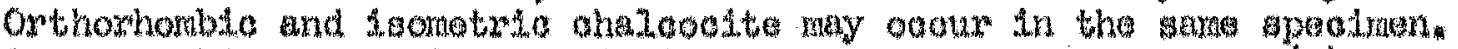

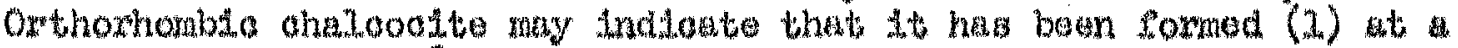

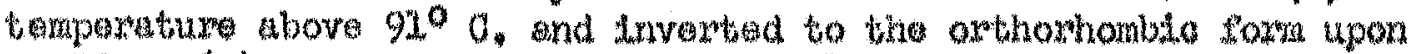

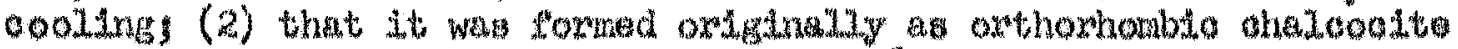
by hot solutions at a tompereture below 9100 (3) that it fomad from

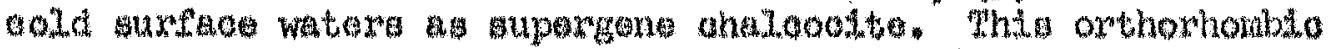

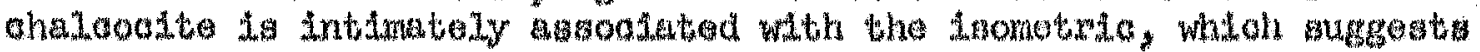
strongly that they wow both wownd from hot volubtom and that the

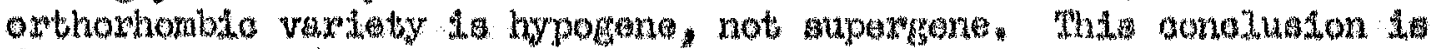

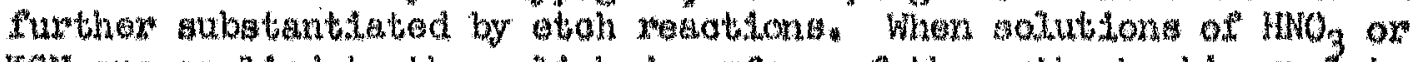
KON

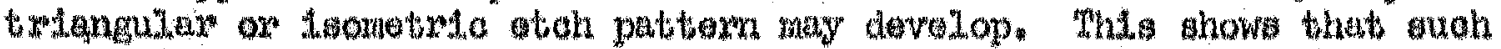

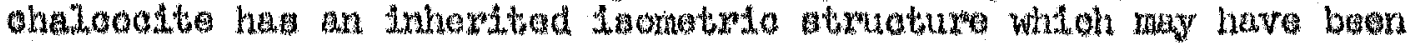

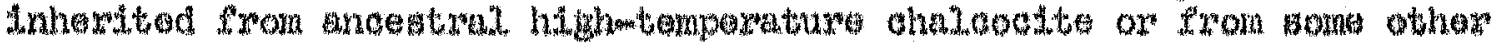

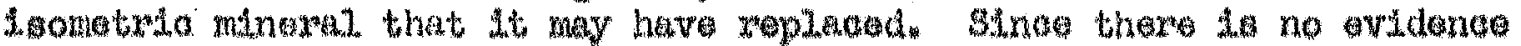

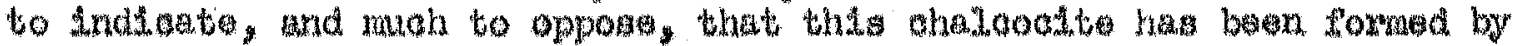

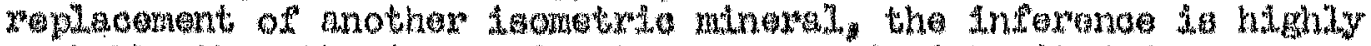

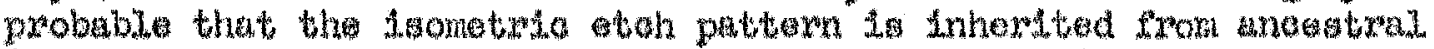

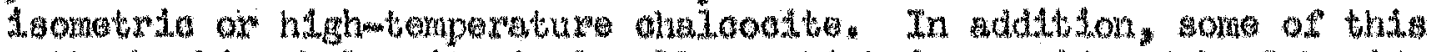

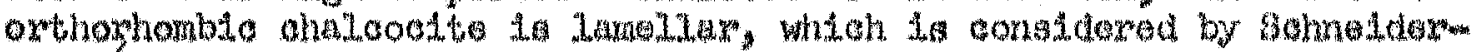

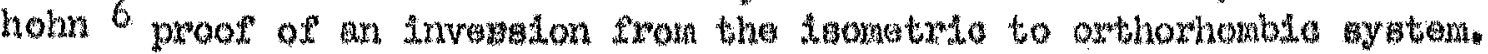

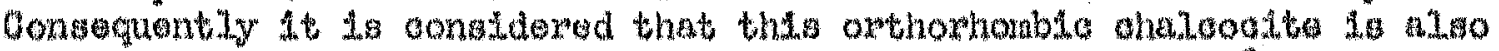

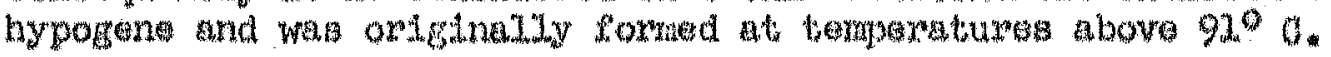

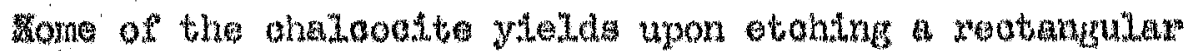

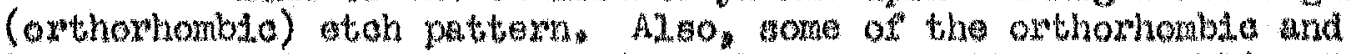

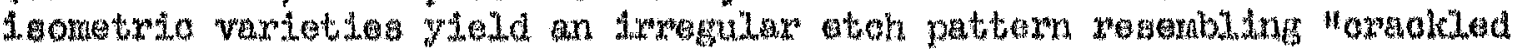

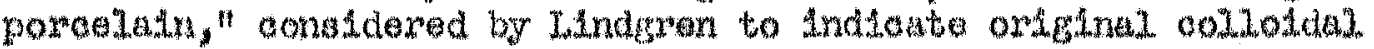

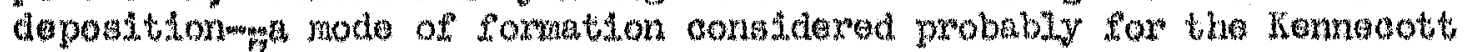
ohaloos 7

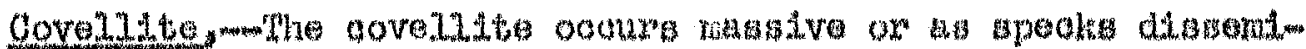

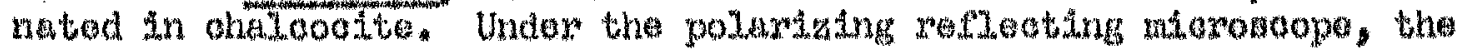

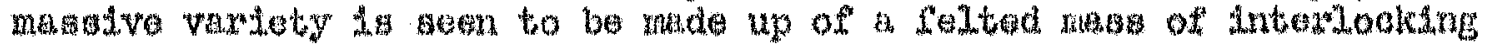

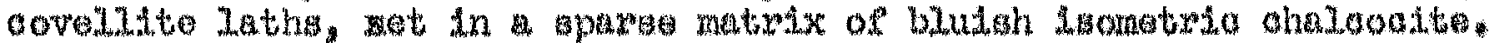

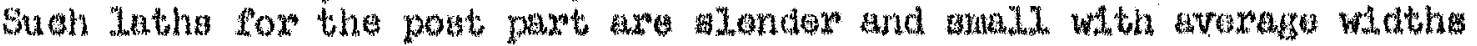

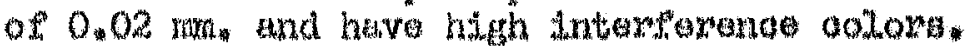

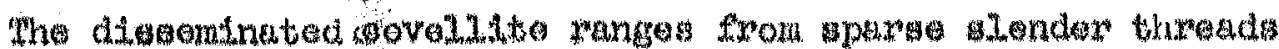

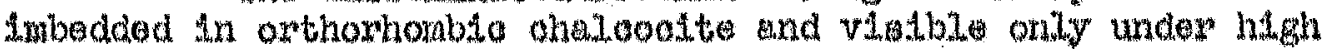

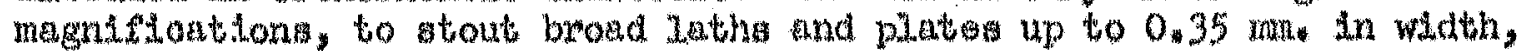

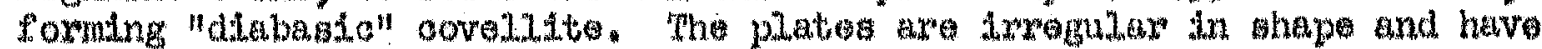

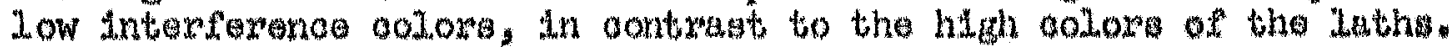




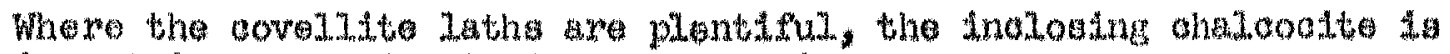
Asometrlo, otherwise it, 19 orthombonbto.

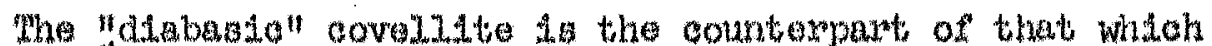

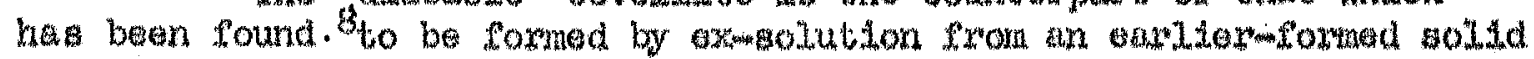

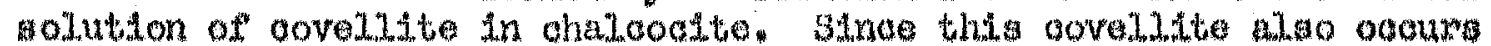

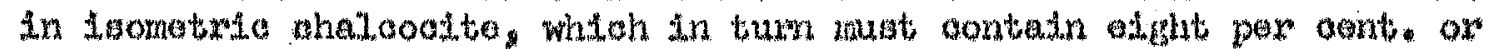

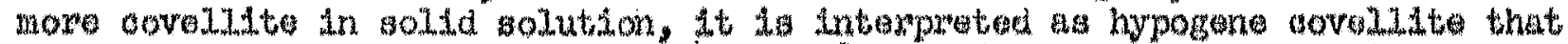
has bean formed above of tamperature of $92^{\circ} \mathrm{C}$. and hea unatxod upon slow

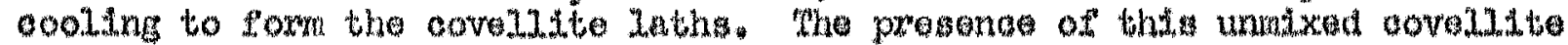

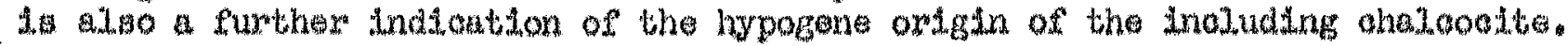

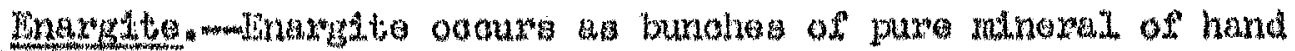

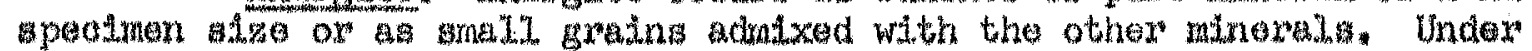

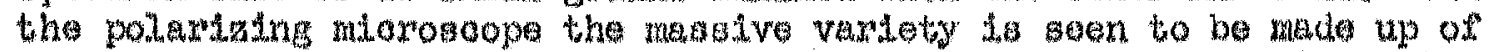

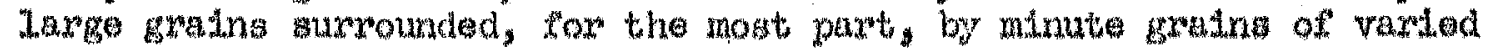

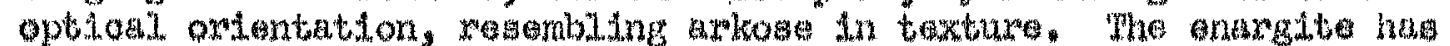

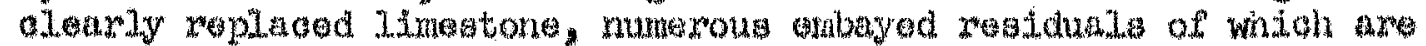
Lnoluded in the enargate gratas

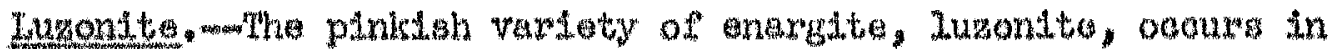

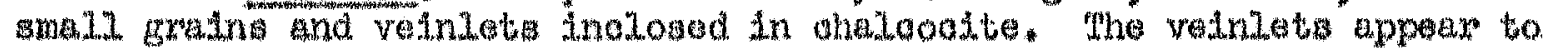

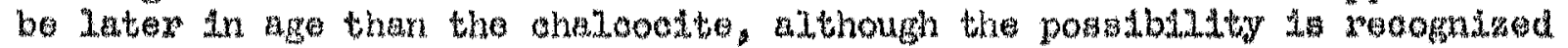

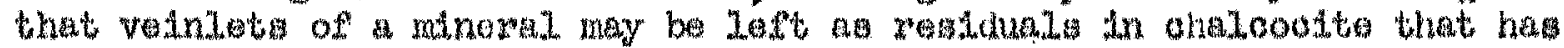
replaced tw.

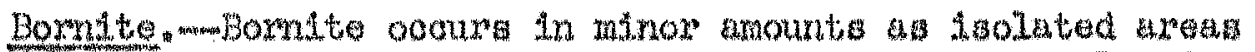

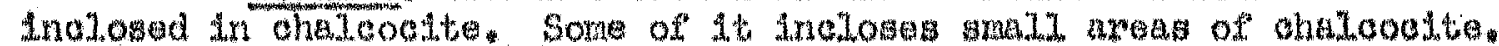

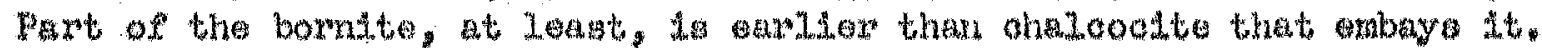
some apperrs to be contaxpodaneous wh the ohalcodate.

Two kinds of bornt te are present; one, the usual Irotxopto

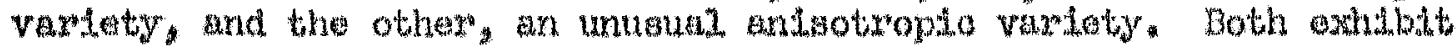

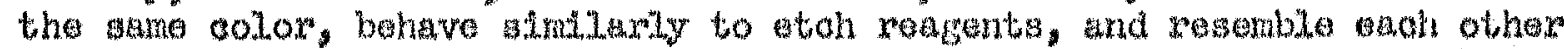

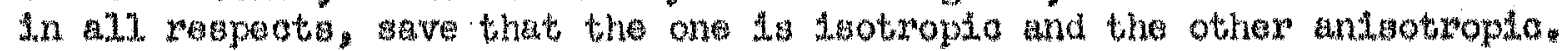

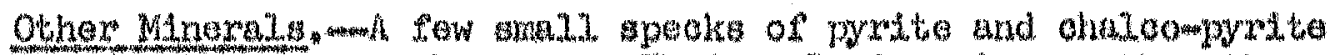

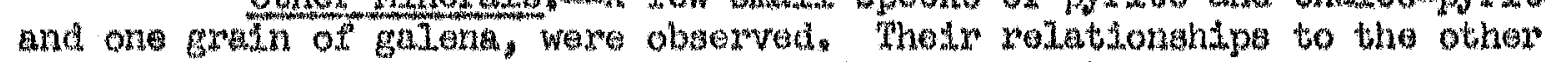

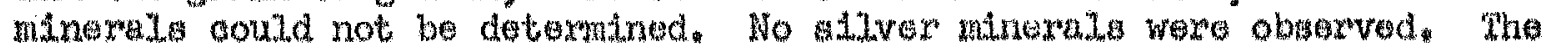

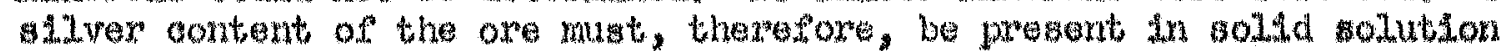
with the ooppere minerels.

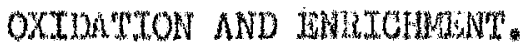

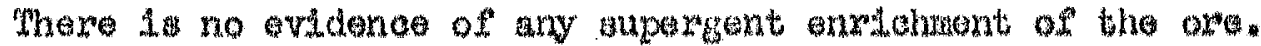

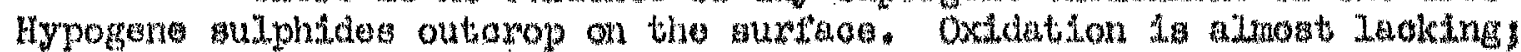

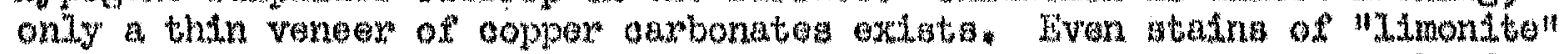
are scarae. The doposit th not favorably stuated fow the preserval of

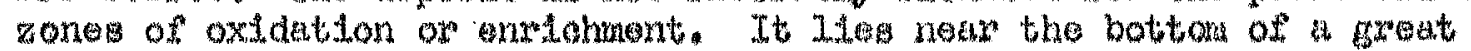

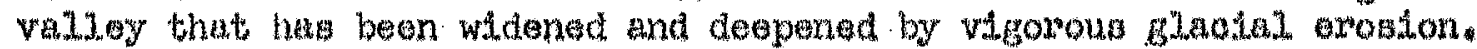

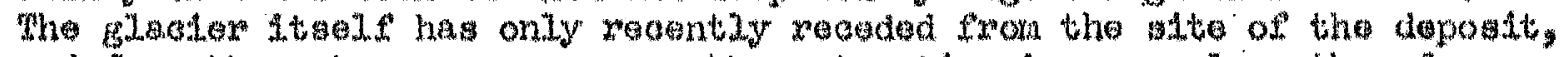

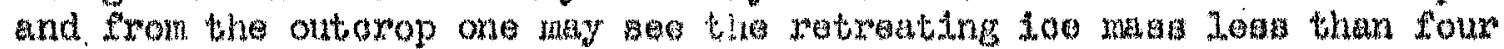

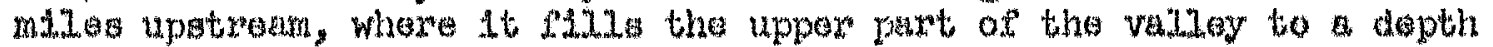

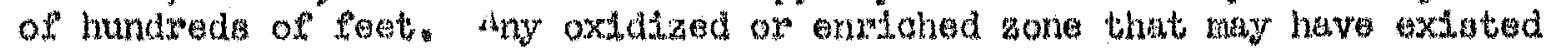
has been eroded away and the time that has olapasd alnoe the axposure of the outcrop to the ary hea been too ghort, and the alinate too cool, for 
new zonea to have bean forred.

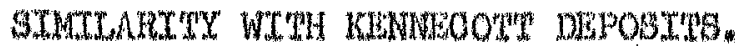

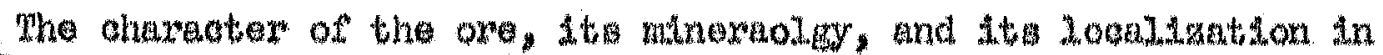

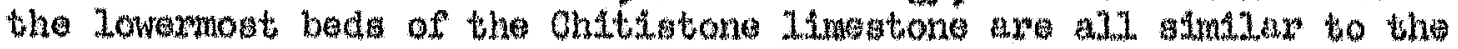

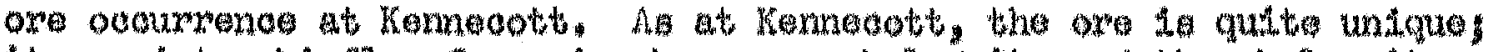

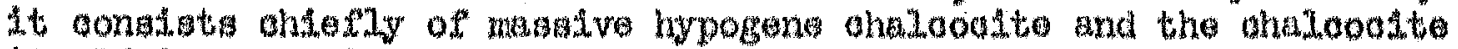

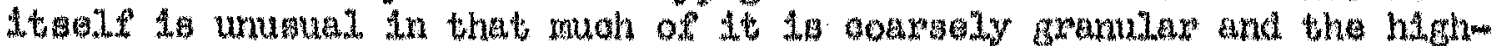

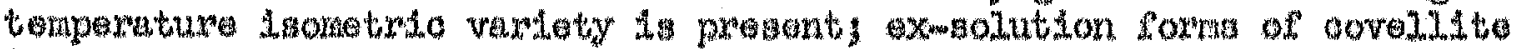

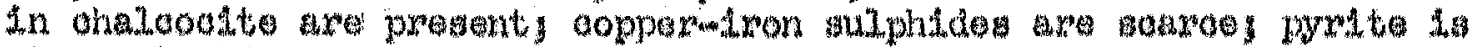

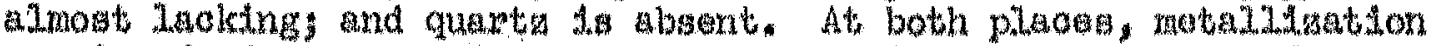

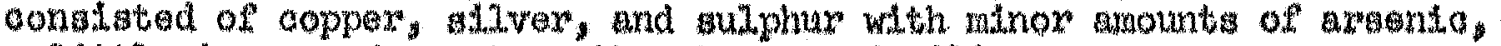

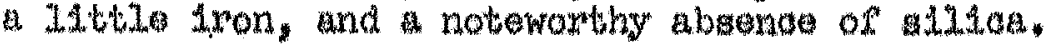

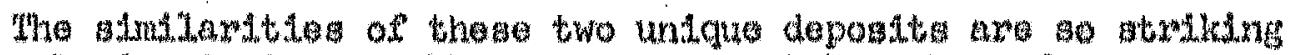
that the oonoluston 1. Inesonpable what they must have baen forwed at

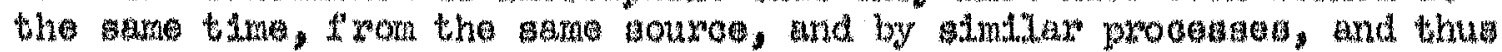

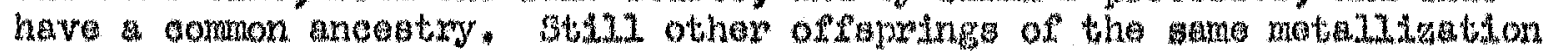

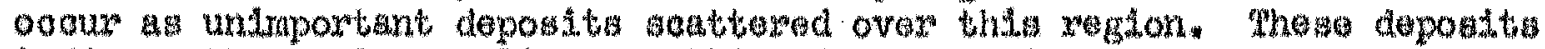

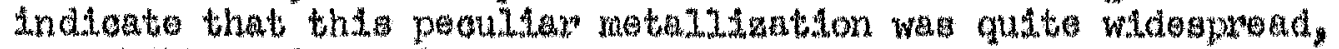

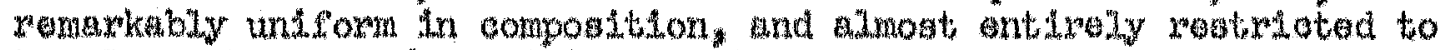
the lower bede of the ondwatione 19 matsone.

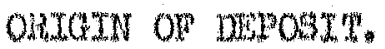

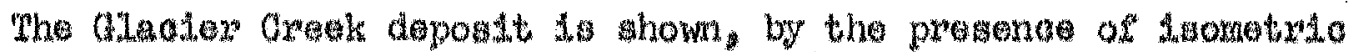

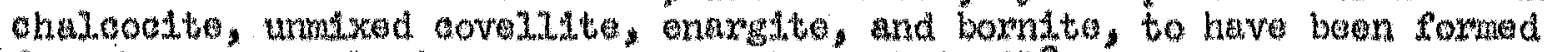
from hypogene solutions at a terperature above $91^{\circ} \mathrm{C}$. The modo of

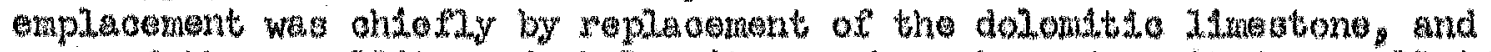

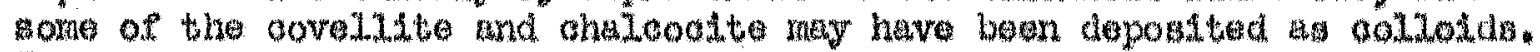

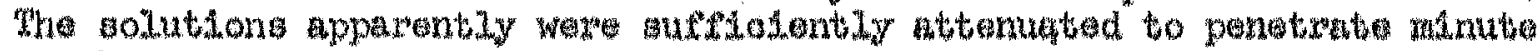
artacher.

As to the acure of the nolutions and of the Introduged notalia,

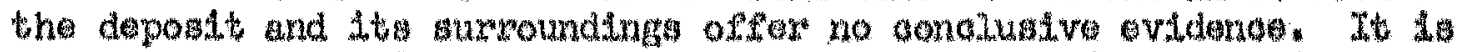

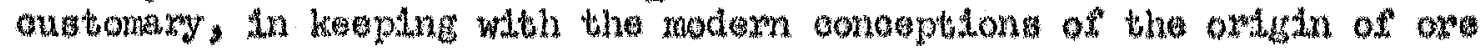

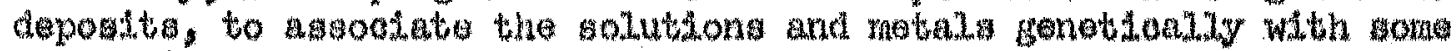

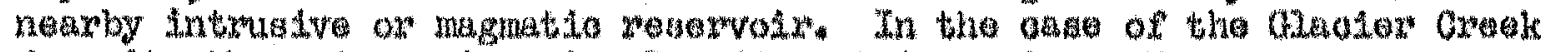

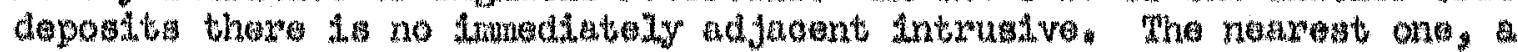

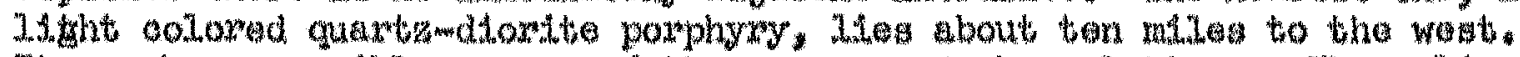

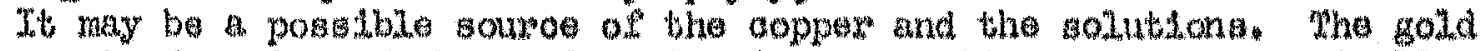

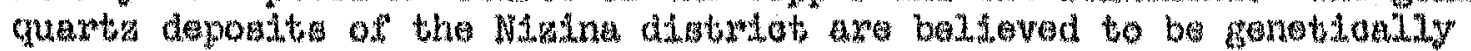

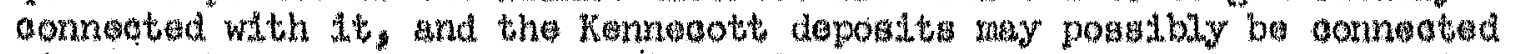

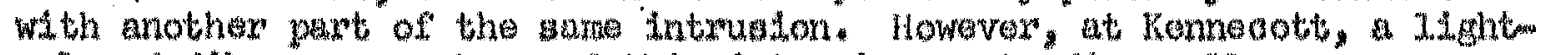

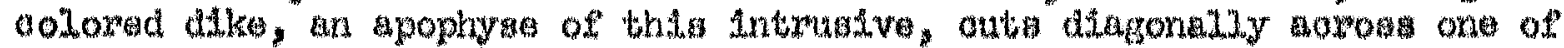

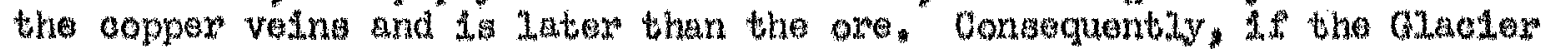

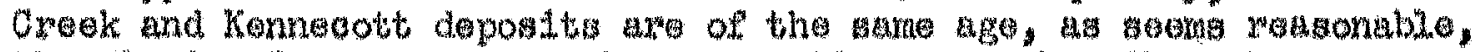

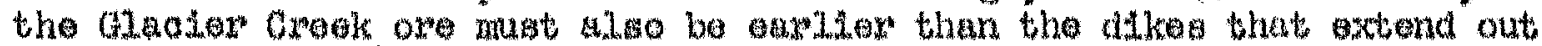

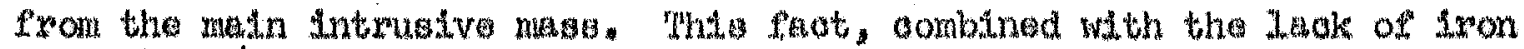

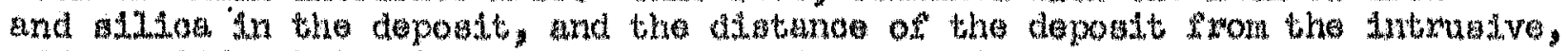
offere diffioulties in the acoeptance of a ganetio comeotion between the

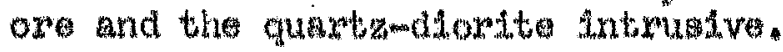




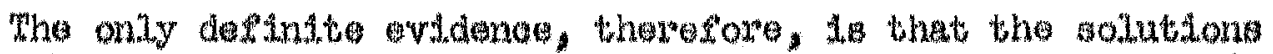

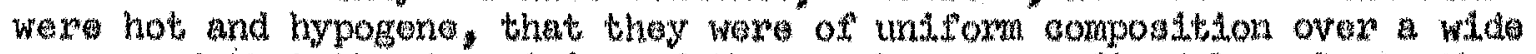

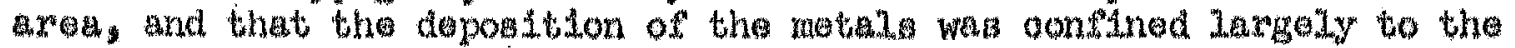

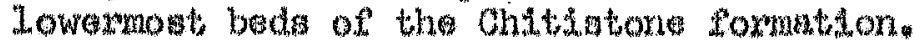

Dabotationy of Deononte Geology

Yale Univor Ity

Now Haven, Oonn:

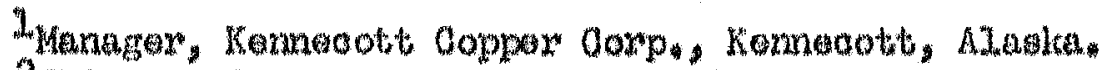

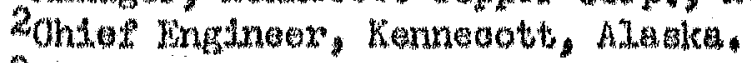

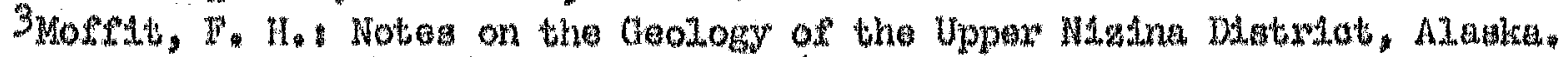

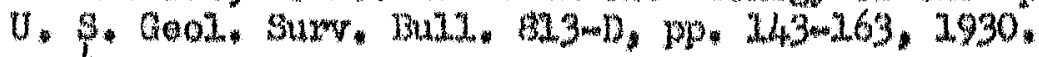

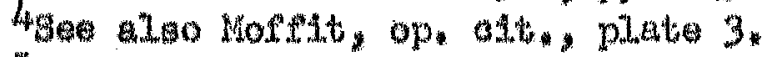

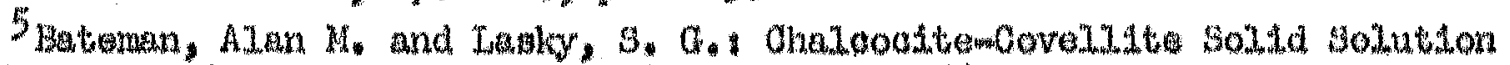

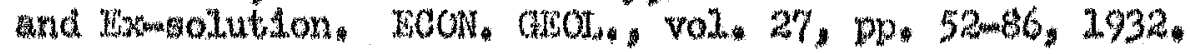

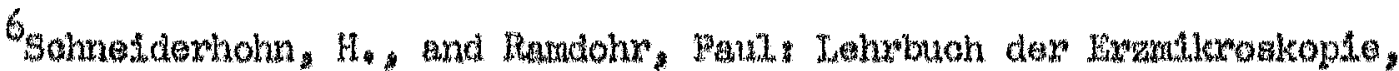

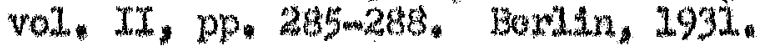

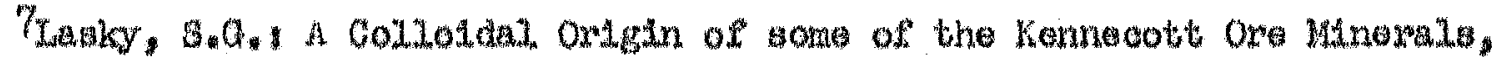
soon. Cool, vol. 25, Dp. 73\%-75\%, 1930.

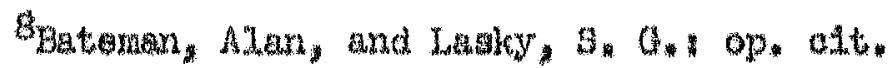

